\title{
Preservice History Teachers' Perceptions of Subject Matter Competency
}

\author{
Tercan Yıldırım ${ }^{1}$, Fatih Yazıc1 ${ }^{2}$ \\ ${ }^{1}$ Department of Social Science Educations, Faculty of Education, Ahi Evran University, Turkey \\ ${ }^{2}$ Department of Social Science Educations, Faculty of Education, Gaziosmanpasa University, Turkey \\ Correspondence: Tercan Yıldırım, Department of Social Science Educations, Faculty of Education, Ahi Evran University, \\ Turkey.
}

Received: August 17, 2017

doi:10.11114/jets.v5i10.2602

\author{
Accepted: September 5, $2017 \quad$ Online Published: September 12, 2017
}

URL: https://doi.org/10.11114/jets.v5i10.2602

\begin{abstract}
Teachers should be able to understand conceptual constructs, viewpoints, and principles related to their field and organize teaching process accordingly. This is valid also for history teachers. They are expected to comprehend the basic conceptions related to subject areas and reflect them on classroom practices. The association between subject matter and pedagogy is significant for the quality of teaching. The drawbacks in content knowledge cause deficiencies in learning and a tendency to handle subjects in a similar manner. The aim of this study was to investigate preservice history teachers' perceptions of content knowledge in terms of different variables. Within this scope, Scale of Perceived Competence in History as a Subject Matter was used as the data collection tool. The participants were composed of 305 preservice history teachers receiving pedagogical formation education at 3 different universities in Turkey during 2016-2017 academic year. In this study, it was investigated whether participants' perceptions of subject matter competency differed in terms of gender, graduation high school, order and reason of choosing the program studied, city of program studied, and general academic average.
\end{abstract}

Keywords: competence, history education, subject matter, preservice teacher, teacher education

\section{Introduction}

Through education, it is desired to raise people as well adjusted members of the society and equip them with contemporary knowledge and skills (Hacioğlu \& Alkan, 1997). When it is considered that its main objective is to train qualified labor and citizens (Karagözoğlu, 2003), a variety of revisions are required to be made with a systematic approach. Qualified teachers along with the social, cultural, scientific, and economic infrastructure are needed for an effective educational system because it is the teachers' duty to ensure quality of the educational system which is composed of many components affecting each other directly or indirectly.

The rapid changes of today have brought with new regulations in terms of quality, novelty, and competency in every profession (Yeşilyurt, 2011). Generally, the education systems or the teacher training are affected from this situation most. The quality of teacher training, which competencies and roles to be possessed, and the problems of teacher training are among the most important debate issues. Based on this situation, the determination of teachers' competency fields have gained importance (Gökçe, 2003; Kahramanoğlu \& Ay, 2013).

Competency can be defined as "knowledge, skills, and attitudes that should be possessed in order to carry out a profession effectively and efficiently" (MEB, 2008a). This definition, also defining the teacher competency, is based on Social Learning Theory. In this theory, individuals' actions of thinking about themselves, judging themselves, and becoming aware of themselves are defined as self-efficacy or self-belief. Accordingly, the people are expected to conduct the necessary activities for a task and become aware of their knowledge and skills while doing that (Bandura, 1986, 1995). Through this approach, which argues that people's beliefs affect their behavior (Ay, 2007), a teacher with high self-efficacy is expected to carry out the teaching process effectively and reach the planned goals. Thus, the teachers' positive judgements about their knowledge and skills are important in terms of coping with the problems and conduct an effective teaching (Özdemir, 2008).

Teacher competencies are generally classified under three categories; general culture, knowledge of the subject matter, and knowledge of teaching profession. Also called as subject matter competency, Shulman (1986) has a major influence on the formation of these categories. Criticizing giving importance only to the knowledge of teaching profession, 
Shulman emphasized that knowledge of the subject matter, knowledge of curriculum, and knowledge of pedagogical content were the real determiners of a quality education (Öner, 2010).Viewed as the main component of teacher competency, the knowledge of subject matter is beyond teachers' knowledge of subject matter. The questions of why and how regarding a topic should be answered. Expressed as the special field, this concept involves knowledge, skills, and attitudes regarding the discipline (Ball, Mcdiormid, 1989; Akçay, 2009). The knowledge of subject matter focuses on the concepts and content of a discipline. This situation is related to organizing how to teach field-specific knowledge and comprehending the basic structure of the field rather than just having the knowledge of subject matter (Shulman, 1987). In other words, it is completely related with the discipline rather than teaching; it involves basic phenomenon, concepts, theories, and ideas and the skills of organizing, assessing, explaining, and verifying. What is expected from a teacher is to become the source of knowledge and skills related to the subject matter and internalize the viewpoint of the field (Kıncal, 2004; Öner, 2010; Özdemir, Yalın \& Sezgin, 2004). Now, the pedagogues and the policy makers are aware of the importance of both pedagogy and the knowledge of subject matter in terms of an effective learning process (Cochran, DeRuiter \& King, 1993: 263).

In Turkey, the teacher competencies were determined in order to be used in determining the teacher training policies, organizing curriculums of the teacher training institutions, providing in-service trainings for the teachers, selecting teachers, evaluating teachers' performances, ensuring the self-knowledge and career developments of teachers (MEB, 2008b). Ministry of National Education (MONE) and Higher Education Council (HEC) carried out many common studies. For example in 1999, teacher competencies were classified under four categories within the scope of HECWorld Bank Project of Improving the National Education; subject matter and field education, the process of teaching-learning, monitoring, evaluating, and recording students' learning, and supplementary professional competencies (Yeşil, 2009).

The teacher competencies were revised in 2002, and were determined as general competencies, general culture, special field, and teaching-educating competencies (Seferoğlu, 2004). Then, within the scope of cooperation between EU and MONE, a significant study on teaching profession general competency called as The Project of Support for Basic Education: The Component of Teacher Education was conducted (MEB, 2006; Candeğer, 2013). With this project, European Teacher and Educator General Competencies, European Competency Framework, and Basic Law of National Education was based on the determination of general competencies (Çalışkan, Işık \& Saygın, 2013). In 2006, The Commission of Teacher Competencies founded under the cooperation of MONE and HEC determined the teaching profession general and special field competencies again (Coşkun, Özer \& Tiryaki; 2010; Kahramanoğlu \& Ay, 2013). Published as a booklet, this study divided the teaching profession competencies into two categories, which were general and special field, and it determined three different levels for each competency: knowledge and awareness (A1), enrichment (A2), and organization and cooperative working (A3) (MEB, 2008a).

Teaching profession general competencies were categorized under 6 main competency fields, which are personal and professional values, knowing the student, learning and teaching process, monitoring and evaluating the learning and development, relationships among the school, family, and society, the knowledge of curriculum and content. A total of 31 sub-competency fields and 233 performance indicators took place under these categories (MEB, 2008b). After determining the teaching profession general field competencies, special field competencies were determined for secondary education teachers in the disciplines such as Turkish Language and Literature, History, Geography, Philosophy, Math, Physics, Chemistry, and Biology within the scope of the Secondary Education Project (MEB, 2011; Candeğer, 2013).

The question of what kinds of qualifications or competencies should be possessed by a good history teacher is sought an answer in direction of both the technical knowledge regarding the teaching profession and the goals of history education (Çulha, 2010; Karabağ, 2010). In an effective history teaching process, the interaction between the teacher's quality and what is expected from history education is present. By the interdisciplinary nature of history education, teacher typologies that are rarely seen in math or science emerge because history teachers are affected by their own experiences and the approach of different thoughts and ideologies on history, and they significant differences among them in terms of teaching-learning processes are observed. The history teachers are generally categorized as storyteller, scientist, and reformist typologies. The existence of history teachers that don't fit any of these typologies and the growing body of research on the teaching-learning process consistently changes what is expected from a good history teacher. History teachers should be trained under a special career education in order for them to have the knowledge, skills, and attitudes to make them competent in their classrooms (Çulha, 2010; Karabağ, 2010). Thus, they will know how their discipline works and this situation will result in deep contextual knowledge regarding the topics to be taught (Kitson, Husband \& Steward, 2011).

Generally, the teachers should be able to understand the field-specific conceptual structures, viewpoints, and principles, and organize the teaching process. This is valid for history teachers as well, and they are expected to comprehend the basic conceptual structures of their subject matter and apply them in their in-class activities. This expectancy is 
mentioned in a variety of studies through deep subject matter knowledge and teaching profession competencies (Barton \& Levstik, 2004). Representing the link between the content and pedagogy, this association express an essential situation for the quality of teaching (Grant, 2003). The deficiencies in the knowledge of subject matter result in weak learning and considering all topics in a similar manner (Smith, 2010). The success of deep subject matter knowledge in correcting or discovering the misunderstandings in classroom can be easily seen (Husband, 2011). However, although the deep subject matter knowledge is among the basic characteristics of a successful history teaching, it is not enough. Teachers' knowledge about history cannot be limited by their knowledge about the historical past. Moreover, history teachers' subject matter knowledge can be limited in a classroom. Sometimes, it is possible for them to plan a learning process based on their wills; however, it is frequently needed to learn novel knowledge and knowledge of near disciplines because of the demands of the curriculum (Husband, 2011).

Recently, the goals of history education have underwent a transformation under the leadership of European Union (EU), and the quality of history teaching and teachers has become a matter of debate. Whent the literature was reviewed, it was observed that although many studies focused on teacher competencies in different disciplines (Arastaman, 2013; Ay, 2007; Aydemir, 2012; Bal \& Karademir, 2013; Dönmez \& Uslu, 2014; Ereş, 2010; Gelbal \& Kelecioğlu, 2007; Gelen \& Özer, 2008; Kahyaoğlu \& Yangın, 2007; Karacaoğlu, 2008; Kök, Çiftçi \& Ayık, 2011; Köksal, 2008; Özbek, Kahyaoğlu \& Özgen, 2007; Taşdemir, 2007; Tunca \& Şahin, 2014; Seferoğlu, 2004; Şahin, 2004; Şeker, Deniz \& Görgen, 2005; Yeşilyurt, 2011), the number of studies focusing on the history teachers' competencies were limited. These studies focused on the preparation process of history teachers' special field competencies (Candeğer, 2014), the effects of courses in history undergraduate programs on these competencies (Candeğer, 2013), pedagogical content knowledge (Bal, 2011; Bozkurt, 2015), and technological pedagogical content knowledge (Bozkurt, 2016). As can be seen, no study directly focused on the history teachers' or preservice teachers' subject matter competencies. The aim of this study is to investigate preservice history teachers' perceptions of their knowledge of subject matter in terms of some variables. Thus, the history curriculums would be evaluated and contribute to revisions of these curriculums. Additionally, the findings are considered to contribute to the process of organizing in-service trainings for teachers.

\section{Method}

\subsection{Research Model}

Relational screening model was used in this study, which aimed at investigating the preservice history teachers' perceptions of their knowledge of subject matter in terms of some variables. Relational screening models are the research models used to find the existence and/or the degree of covariance between two or more number of variables (Karasar, 2005).

\subsection{Participants}

The participants of this study were composed of 305 preservice history teachers receiving pedagogical formation education at 3 different universities in Turkey during 2016-2017 academic year. 197 participants were female (65\%), and 96 were male (32\%). 182 participants graduated from general high school; 45 graduated from Anatolian High School; 32 graduated from Vocational High School; 9 graduated from Religious Vocational High School; 7 graduated from Anatolian Vocational High School; 6 graduated from Private High School; 5 graduated from Open High School; 3 graduated from Anatolian Religious Vocational High School; and 3 graduated from Anatolian Teacher Training High School. When their reasons of choosing the department they graduated were examined, it was observed that 213 chose it willingly; 58 chose it so as not to be unattached to university; 10 chose it because of their families' wills. Their distribution of GPA is as follows: 1 preservice teacher is between 30 and 53; 19 are between 54 and 63; 93 are between 64 and 74; 146 are between 75 and 86; and 28 are between 87 and 100 .

\subsection{Data Collection Tools}

Demographics information form and the Scale of Perceived Competence in History as a Subject Matter (SPCHSM) were used to gather data.

Demographic information form was prepared for this study and it includes personal information such as gender, high school that was graduated, university that was/is graduated/studied, order and reason of choosing the department studied, and GPA.

Scale of Perceived Competence in History as a Subject Matter: Aiming at measuring history teachers' perceptions of subject matter competencies, SPCHSM was developed by Yildırım \& Yazıc1 (2017). Special field competencies of history teachers, which were developed by Ministry of National Education, served as foundation for the development of SPCHSM (MEB, 2011). SPCHSM is composed of 4 factors and a total of 21 items. The factors are named as Historiography, Pre-Ottoman Turkish History, Post-Ottoman Turkish History, and World History. Items of SPCHSM are rated on a 5-point Likert scale from 1 (inadequate) to 5 (substantially adequate). 
Exploratory factor analysis (EFA) was conducted in order to determine the construct validity of SPCHSM. Kaiser Meyer Olkin (KMO) and Bartlett test was used to decide whether the data was suitable for EFA. KMO value was found to be .92 and Bartlett test was found to be significant $\left(\chi^{2}(210)=3349.27 ; p<.01\right)$. According to EFA, four factorial construct explained $62.51 \%$ of the variance. Factor loadings ranged between .43 and .84 . Subsequent to EFA, confirmatory factor analysis (CFA) was conducted. Chi-square was found significant in CFA $\left(\chi^{2}=368.87, \mathrm{df}=183, \mathrm{p}\right.$ $\left.=.00, \chi^{2} / \mathrm{df}=2.01\right)$. Other goodness of fit indexes were found as: RMSEA $=.058, \mathrm{GFI}=.90, \mathrm{CFI}=.98, \mathrm{NFI}=.96$, RFI $=.96$, AGFI $=.87$, IFI $=.98$ and NNFI $=.98$. Cronbach's Alpha internal consistency coefficient of the scale was estimated to be. 92 .

\subsection{Data Analysis}

The data of the study was analyzed using SPSS 20 and LISREL 8.80 software. Mean scores and standard deviation values of preservice history teachers' perceptions of subject matter competencies were estimated. T-test was used in order reveal the differences in participants' perceptions of subject matter competencies in terms of gender, high school that was graduated, university that was/is graduated/studied, and order and reason of choosing the department studied. One -way variance analysis (ANOVA) was used for GPA.

\section{Results}

The mean scores of participants' responses regarding their perceptions of their competencies of history subject matter were estimated for each dimension. The findings are presented in Table 1.

Table 1. Preservice history teachers' perceptions of history subject matter competencies

\begin{tabular}{lllll}
\hline Dimension & $\overline{\boldsymbol{x}}$ & Sd & Min. & Max. \\
\hline Historiography & 3,82 &, 65 & 1,17 & 5 \\
Pre-Ottoman Turkish History & 3,60 &, 74 & 1,50 & 5 \\
Post-Ottoman Turkish History & 4,04 &, 68 & 1,60 & 5 \\
World History & 3,69 & 1,33 & 1,33 & 5 \\
\hline Total & 3,79 &, 55 & 1,80 & 4,92 \\
\hline
\end{tabular}

As can be seen in the Table 1, the participants obtained the lowest scores from Pre-Ottoman Turkish History and World History while they got the highest scores from Post-Ottoman Turkish History. T-test was performed in order to reveal the influence of gender on preservice history teachers' perceptions of history subject matter competency. The findings are presented in Table 2.

Table 2. Preservice history teachers' perceptions of history subject matter competency in terms of gender

\begin{tabular}{|c|c|c|c|c|c|c|c|}
\hline \multirow[t]{2}{*}{ Dimension } & \multirow[t]{2}{*}{ Gender } & \multirow[t]{2}{*}{$\mathbf{n}$} & \multirow[t]{2}{*}{$\bar{x}$} & \multirow[t]{2}{*}{ Sd } & \multicolumn{3}{|c|}{$t$ - Test } \\
\hline & & & & & $t$ & sd & p \\
\hline \multirow[t]{2}{*}{ Historiography } & Female & 197 & 3,80 & ,67 & & & \\
\hline & Male & 96 & 3,85 & ,65 &,- 659 & 312 & ,511 \\
\hline \multirow[t]{2}{*}{ Pre-Ottoman Turkish History } & Female & & 3,52 & ,73 & & & \\
\hline & Male & & 3,78 & ,78 & $-2,774$ & & ,006* \\
\hline \multirow[t]{2}{*}{ Post-Ottoman Turkish History } & Female & & 4,03 & ,68 & & & \\
\hline & Male & & 4,08 & ,71 &,- 586 & & ,558 \\
\hline \multirow[t]{2}{*}{ World History } & Female & & 3,67 &, 73 & & & \\
\hline & Male & & 3,72 & ,68 &,- 600 & & ,549 \\
\hline \multirow[t]{2}{*}{ Total } & Female & & 3,75 &, 55 & & & \\
\hline & Male & & 3,86 &, 59 & $-1,482$ & & ,139 \\
\hline
\end{tabular}

$* \mathrm{P}<.05$

As can be seen in Table 2, the gender didn't create a difference in participants scores obtained from three subscales and the whole scale, while it caused a significant difference in their scores obtained from the subscale of Pre-Ottoman Turkish History at $\mathrm{p}<.01$ level. Accordingly, male participants higher perceptions of competency regarding Pre-Ottoman Turkish History than female participants.

In order to determine the effect of high school that was graduated on the perceptions of history subject matter, the high schools were divided into two categories as Anatolian High School and the others. The results of the t-test are presented in Table 3. 
Table 3. Preservice history teachers' perceptions of history subject matter competency in terms of the high school

\begin{tabular}{|c|c|c|c|c|c|c|c|c|}
\hline \multirow[t]{2}{*}{ Dimension } & \multirow[t]{2}{*}{ High School } & & \multirow[t]{2}{*}{$\mathbf{n}$} & \multirow[t]{2}{*}{$\overline{\boldsymbol{x}}$} & \multirow[t]{2}{*}{ Sd } & \multicolumn{3}{|c|}{$t$-Test } \\
\hline & & & & & & $t$ & sd & $\mathbf{p}$ \\
\hline \multirow[t]{2}{*}{ Historiography } & $\begin{array}{l}\text { Anatolian } \\
\text { School }\end{array}$ & High & 48 & 3,95 & ,72 & 1,532 & \multirow{4}{*}{291} &, 127 \\
\hline & Others & & \multirow[t]{9}{*}{245} & 3,79 & ,65 & & & \\
\hline \multirow[t]{2}{*}{ Pre-Ottoman Turkish History } & $\begin{array}{l}\text { Anatolian } \\
\text { School }\end{array}$ & High & & 3,77 & ,83 & 1,676 & & ,095 \\
\hline & Others & & & 3,57 & ,74 & & & \\
\hline \multirow[t]{2}{*}{ Post-Ottoman Turkish History } & $\begin{array}{l}\text { Anatolian } \\
\text { School }\end{array}$ & High & & 4,22 & ,77 & 1,979 & &, $049 *$ \\
\hline & Others & & & 4,01 & 67 & & & \\
\hline \multirow[t]{2}{*}{ World History } & $\begin{array}{l}\text { Anatolian } \\
\text { School }\end{array}$ & High & & 3,87 & ,64 & 1,971 & &, $050 *$ \\
\hline & Others & & & 3,65 & ,72 & & & \\
\hline \multirow[t]{2}{*}{ Total } & $\begin{array}{l}\text { Anatolian } \\
\text { School }\end{array}$ & High & & 3,95 & ,63 & 2,243 & &, $026^{*}$ \\
\hline & Others & & & 3,75 & .55 & & & \\
\hline
\end{tabular}

$* \mathrm{P}<.05$

As can be seen in Table 3, the high school didn't create a difference in participants scores obtained from two subscales and the wholescale. The participants who were graduated from Anatolian High School obtained significantly higher scores from Pre-Ottoman Turkish History, Post-Ottoman Turkish History, and the whole scale than the participants who were graduated from other high schools at $\mathrm{p}<.05$ level.

In order to determine the effect of their reason of choosing the department studied on the perceptions of history subject matter, the reasons were divided into two categories as choosing willingly and others. The results of the t-test are presented in Table 4.

Table 4. Preservice history teachers' perceptions of history subject matter competency in terms of their reasons of choosing the department

\begin{tabular}{|c|c|c|c|c|c|c|c|}
\hline \multirow[t]{2}{*}{ Dimension } & \multirow{2}{*}{$\begin{array}{l}\text { Reason of } \\
\text { Choosing }\end{array}$} & \multirow[t]{2}{*}{$\mathbf{n}$} & \multirow[t]{2}{*}{$\bar{x}$} & \multirow[t]{2}{*}{ Sd } & \multicolumn{3}{|c|}{$t$-Test } \\
\hline & & & & & $t$ & sd & $\mathbf{p}$ \\
\hline \multirow[t]{2}{*}{ Historiography } & Choosing willingly & 213 & 3,88 & ,65 & 2,748 & & ,006* \\
\hline & Others & 76 & 3,64 & 67 & & 287 & \\
\hline \multirow[t]{2}{*}{ Pre-Ottoman Turkish History } & Choosing willingly & & 3,67 & ,77 & 2,513 & &, $013 *$ \\
\hline & Others & & 3,42 &, 72 & & & \\
\hline \multirow[t]{2}{*}{ Post-Ottoman Turkish History } & Choosing willingly & & 4,10 & 67 & 2,684 & &, $008 *$ \\
\hline & Others & & 3,86 &, 73 & & & \\
\hline \multirow[t]{2}{*}{ World History } & Choosing willingly & & 3,70 & ,71 & ,541 & & ,589 \\
\hline & Others & & 3,64 &, 75 & & & \\
\hline \multirow[t]{2}{*}{ Total } & Choosing willingly & & 3,84 &, 56 & 2,635 & &, $009 *$ \\
\hline & Others & & 3,64 &, 55 & & & \\
\hline
\end{tabular}

$* \mathrm{P}<.05$

As can be seen in Table 4, participants' reasons of choosing the department created a difference in their scores obtained from three subscales and the wholescale. The participants who chose the department willingly obtained significantly higher scores from Historiography, Pre-Ottoman Turkish History, Post-Ottoman Turkish History, and the whole scale at $\mathrm{p}<.05$ level.

In order to determine the effect of order of choosing the department studied on the perceptions of history subject matter, the orders were divided into two categories as the first order and the others. The results of the t-test are presented in Table 5. 
Table 5. Preservice history teachers' perceptions of history subject matter competency in terms of the order of choosing the department

\begin{tabular}{|c|c|c|c|c|c|c|c|}
\hline \multirow[t]{2}{*}{ Dimension } & \multirow[t]{2}{*}{ Order of Choice } & \multirow[t]{2}{*}{$\mathbf{n}$} & \multirow[t]{2}{*}{$\bar{x}$} & \multirow[t]{2}{*}{ Sd } & \multicolumn{3}{|c|}{$t$-Test } \\
\hline & & & & & $t$ & sd & $\mathbf{p}$ \\
\hline \multirow[t]{2}{*}{ Historiography } & First Order & 53 & 3,88 & ,67 & ,813 & \multirow{4}{*}{259} & ,417 \\
\hline & Others & 208 & 3,80 & ,66 & & & \\
\hline \multirow[t]{2}{*}{ Pre-Ottoman Turkish History } & First Order & & 3,76 & ,63 & 1,902 & & ,058 \\
\hline & Others & & 3,54 &, 79 & & & \\
\hline \multirow[t]{2}{*}{ Post-Ottoman Turkish History } & First Order & & 4,21 & ,70 & 1,885 & & ,061 \\
\hline & Others & & 4,01 & ,68 & & & \\
\hline \multirow[t]{2}{*}{ World History } & First Order & & 3,83 & ,74 & 1,696 & & ,091 \\
\hline & Others & & 3,64 & ,72 & & & \\
\hline \multirow[t]{2}{*}{ Total } & First Order & & 3,92 &, 57 & 1,989 & &, $048 *$ \\
\hline & Others & & 3,75 &, 57 & & & \\
\hline
\end{tabular}

$* \mathrm{P}<.05$

As can be seen in Table 5, participants' order of choosing the department didn't create a difference in their scores obtained from three subscales; however, it created a significant difference in their scores obtained from the whole scale. Accordingly, the participants whose department was their first choice had significantly higher competencies of history subject matter than others at $\mathrm{p}<.05$ level.

In order to determine the effect of participants' GPA on the perceptions of history subject matter, the participants were divided into four categories in four point grade system in terms of their GPAs. The categories were as: 2.4 or below; between 2.5 and 2.9; between 3.0 and 3.4; and between 3.5 and 4.0. One-way factor analysis was conducted in order to determine the differences among the groups. The results are presented in Table 6.

Table 6. Preservice history teachers' perceptions of history subject matter competency in terms of their GPA

\begin{tabular}{|c|c|c|c|c|c|c|}
\hline Dimension & $\begin{array}{l}\text { Source of the } \\
\text { Variation }\end{array}$ & $\begin{array}{l}\text { Sum of } \\
\text { Squares }\end{array}$ & sd & $\begin{array}{l}\text { Mean sum of } \\
\text { Squares }\end{array}$ & $\mathbf{F}$ & $\mathbf{P}$ \\
\hline \multirow[t]{3}{*}{ Historiography } & Between Groups & 4,447 & 3 & 1,482 & \multirow[t]{3}{*}{3,595} & \multirow[t]{3}{*}{,014* } \\
\hline & Within Groups & 116,699 & 283 & ,412 & & \\
\hline & Total & 121,146 & 286 & & & \\
\hline \multirow[t]{3}{*}{ Pre-Ottoman Turkish History } & Between Groups & 2,223 & & ,741 & \multirow[t]{3}{*}{1,296} & \multirow[t]{3}{*}{,276 } \\
\hline & Within Groups & 161,845 & &, 572 & & \\
\hline & Total & 164,067 & & & & \\
\hline \multirow[t]{3}{*}{ Post-Ottoman Turkish History } & Between Groups & 3,611 & & 1,204 & \multirow[t]{3}{*}{2,598} & \multirow[t]{3}{*}{053} \\
\hline & Within Groups & 131,081 & & 463 & & \\
\hline & Total & 134,692 & & & & \\
\hline \multirow[t]{3}{*}{ World History } & Between Groups & 2,874 & & ,958 & \multirow[t]{3}{*}{1,879} & \multirow[t]{3}{*}{, 133} \\
\hline & Within Groups & 144,288 & & 510 & & \\
\hline & Total & 147,163 & & & & \\
\hline \multirow[t]{3}{*}{ Total } & Between Groups & 2,372 & & ,791 & \multirow[t]{3}{*}{2,527} & \multirow[t]{3}{*}{,058 } \\
\hline & Within Groups & 88,561 & & ,313 & & \\
\hline & Total & 90,933 & & & & \\
\hline
\end{tabular}

$* \mathrm{P}<.05$

According to ANOVA results, the participants' GPA didn't create a significant difference except for the Historiography subscale. Scheffe test was performed in order to determine which groups' scores differed significantly. The results showed that the participants with a GPA between 3.0 and $3.4\left({ }^{X}=3,88\right)$ and the participants with a GPA between 3.5 and $4.0\left({ }^{X}=3,99\right)$ had significantly higher scores from the Historiography subscale than the participants with a GPA of 2.4 or below at $\mathrm{p}<.05$ level.

In order to determine the effect of the university that was studied on the perceptions of history subject matter, the universities were divided into two categories as large cities (i.e. Istanbul and Ankara) and rural. T-test was conducted in order to determine whether the participants' scores differed. The t-test results are presented in Table 7. 
Table 7. Preservice history teachers' perceptions of history subject matter competency in terms of their University

\begin{tabular}{|c|c|c|c|c|c|c|c|}
\hline \multirow[t]{2}{*}{ Dimension } & \multirow[t]{2}{*}{ University } & \multirow[t]{2}{*}{$\mathbf{n}$} & \multirow[t]{2}{*}{$\overline{\boldsymbol{x}}$} & \multirow[t]{2}{*}{ Sd } & \multicolumn{3}{|l|}{$t$-Test } \\
\hline & & & & & $t$ & sd & $\mathbf{p}$ \\
\hline \multirow[t]{2}{*}{ Historiography } & Large City & 71 & 3,99 &, 58 & 2,511 & & ,013* \\
\hline & Rural & 216 & 3,76 & 68 & & 285 & \\
\hline \multirow{2}{*}{ Pre-Ottoman Turkish History } & Large City & & 3,66 & 87 & ,719 & & ,473 \\
\hline & Rural & & 3,59 & ,71 & & & \\
\hline \multirow[t]{2}{*}{ Post-Ottoman Turkish History } & Large City & & 4,31 & ,64 & 3,907 & &, $000 *$ \\
\hline & Rural & & 3,95 & ,68 & & & \\
\hline \multirow[t]{2}{*}{ World History } & Large City & & 3,90 &, 76 & 3,102 & &, $002 *$ \\
\hline & Rural & & 3,60 & ,69 & & & \\
\hline \multirow[t]{2}{*}{ Total } & Large City & & 3,97 & ,56 & 3,150 & &, $002 *$ \\
\hline & Rural & & 3,73 &, 55 & & & \\
\hline
\end{tabular}

$* \mathrm{P}<.05$

As can be seen in Table 7, participants' universities created a difference in their scores obtained from three subscales and the whole scale. Accordingly, participants studying at universities in large cities such as Istanbul and Ankara obtained significantly higher scores from Historiography, Post-Ottoman Turkish History, the World History, and the whole scale than the participants studying in rural cities at $\mathrm{p}<.05$ level.

\section{Discussion and Conclusion}

In this study, preservice history teachers' perceptions of subject matter competency were investigated in terms of some variables. The participants' mean score obtained from SPCHSM were estimated to be ${ }^{X}=3,79$. This score shows that preservice history teachers' perceptions of subject matter competency were at a sufficient level. Although it shows the self-confidence of preservice history teachers about professional competency, it also has a potential of causing negativity about developing themselves in historical content knowledge. Moreover, in a study conducted by Bozkurt (2015), the mean score of preservice history teachers' perceptions of subject matter competency was estimated to be ${ }^{X}$ $=3,77$. This finding demonstrates the close relationship between content knowledge education and subject matter.

When the participants' scores obtained from subscales were examined, it was observed that they obtained the lowest scores from Pre-Ottoman Turkish History and World History while they got the highest scores from Post-Ottoman Turkish History. Their low scores of World History can be explained by the limited number of courses related to world history while the courses on Turkish History have a major place in programs (Erkan, 2011). Moreover, the emphasis on world history has been decreasing since 1980s. This decrease can cause preservice history teachers to have a limited perception related to world history. Additionally, the courses related to worlds history is limited by European history (i.e. Western European History). This can also adversely affect perceptions of world history (Öztürk, 2016). History education programs don't aim at handling Turkish history within the frame of world history. Thus, it is expected that this situation will remain the same for a while.

While dominant Turkish history in history departments programs adversely affect the perceptions of world history, focusing on some points in Turkish history causes some differences in preservice history teachers' perceptions of Turkish history. The majority of history courses in programs focuses on Ottoman history since it both has a long history and is related to a variety of other countries and societies. Course contents such as Ottoman Empire's political history, institutions, economy, society, culture, modernization, and diplomacy (Gündüz, 2011) may be the reason of high perceptions of Post-Ottoman Turkish History and of low perceptions of Pre-Ottoman Turkish History.

The results showed that the gender didn't create a difference in participants' perceptions of subject matter competency except for only one subscale of SPCHSM. The studies carried out in different branches and competency perceptions reveal that gender isn't a determiner variable on competency perceptions (Altunçekiç, Yaman \& Koray, 2005; Bozkurt, 2015; Coşkun, Gelen \& Öztürk, 2009; Coşkun, Özer \& Tiryaki, 2010; Kahramanoğlu \& Ay, 2013).

The results showed that participants studied at universities in large cities such as Istanbul and Ankara had higher perceptions of subject matter competencies than their counterparts from smaller cities. This difference can be explained by the quality problems of universities in smaller cities. Some issues such as mild requirements to found history departments (Gündüz, 2011), ignoring infrastructure while founding departments, and lack of sufficient number of academics in smaller cities can be considered as the reasons behind participants low perceptions of subject matter competencies (Yüksel, 2011).

The order of choosing history department created a significant difference in participants' perceptions. Competency perceptions of participants, whose first choice was history education, were significantly higher than other participants. 
Similarly, competency perceptions of participants, who willingly chose to study history education, were higher. These results showed that the interest and willingness related to choosing history department was an important source of motivation during the undergraduate education.

The high school of the preservice history teachers was another effective variable on their perceptions of subject matter competency. It created a significant difference in their scores obtained from two subscales and the whole scale. The participants who were graduated from Anatolian High School obtained significantly higher scores from Pre-Ottoman Turkish History, Post-Ottoman Turkish History, and the whole scale than the participants who were graduated from other high schools. On the other hand, participants' GPA didn't create a significant difference in their perceptions of subject matter competency except for the Historiography subscale.

In this study, which investigated preservice history teachers' perceptions of subject matter competencies in terms of different variables, it was observed that participants perceived themselves as competent related to subject matter. At this point, the difference between "perceiving as competent" and "being competent" presents a negation since "being unaware of real competencies" may cause a variety of problems in classroom activities, prevent them from developing themselves, and pose an obstacle for them to maintain up-to-date. The difference in participants' perceptions in terms of the size of cities requires a questioning of the quality of universities in smaller cities. Low scores obtained from Pre-Ottoman Turkish History and World History are another reason of debate in general.

\section{References}

Akçay, S. (2009). A Study on Primary Education Preservice Science Teacher Knowledge in the Subject Area of Biology. Gazi University Journal of Gazi Educational Faculty, 29(3), 709-713.

Altunçekiç, A., Yaman, S., \& Koray, Ö. (2005). The Research On Prospective Teachers' Self Efficacy Belief Level and Problem Solving Skills. Kastamonu Eğitim Dergisi, 13(1), 93-102.

Arastaman, G. (2013). Examination of Education and Arts and Sciences Faculty Students' Self-Efficacy Beliefs and Their Attitudes Toward Teaching Profession. Ahi Evran Üniversitesi Kırşehir Eğitim Fakültesi Dergisi, 14(2), 205-217.

Ay, B. (2007). Teacher's self-efficacy and organizational citizenship behaviour. Unpublished master's thesis, Afyon Kocatepe University, Afyon.

Aydemir, H. (2012). Competencies of Social Sciences Teachers in Using Teaching Methods, Techniques and Strategies. Hikmet Yurdu, 5(9), 81-100.

Bal, M. S. (2011). Examining the Pre-Service History Teachers' Pedagogical Content Knowledge Regarding The Crusades. Selçuk Üniversitesi Ahmet Keleşoğlu Eğitim Fakültesi Dergisi, 31, 239-261.

Bal, M. S., \& Karademir, N. (2013). Determining Social Science Teachers' Self-Assessment Levels With Regard To Their Technological Pedagogical Content Knowledge (TPCK). Pamukkale Üniversitesi Eğitim Fakültesi Dergisi, 34(2), 15-32.

Bandura, A. (1986). Social foundations of though tandaction: A social cognitive theory. EnglewoodCliffs, NJ: Prentice-Hall.

Bandura, A. (1995). New Self-efficacy in changing societies. York: Cambridge University Press.https://doi.org/10.1017/CBO9780511527692

Barton, K. C., \& Levstik, L. S. (2004). Teaching history fo rthe common good. Mahwah: Lawrence Erlbaum Associates.

Bozkurt, N. (2015). Determining the History Teacher Candidates' Efficacy in the Special Field Competencies. Uşak Universitesi Sosyal Bilimler Dergisi, 8(3), 65-86.

Bozkurt, N. (2016). Determination of Self-Confidence for Technological Pedagogical Content Knowledge of Pre-Service History Teacher. Mustafa Kemal Üniversitesi Sosyal Bilimler Enstitüsü Dergisi, 13(33), 153-167.

Candeğer, Ü. (2013). Comparison of Special Area Competences and Course Programs in Web Pages of History Teacher Departments.Uşak Üniversitesi Sosyal Bilimler Dergisi, Özel Sayl, 329-346.

Candeğer, Ü. (2014). Preparation of History Teacher Special Field Competences. Turkish History Education Journal, 4(1), 177-194.

Cochran, K. F., DeRuiter, J. A., \& King, R. A. (1993). Pedagogicalcontentknowledge: an integrative model forteacher preparation. Journal of Teacher Education, 44(14), 263-272. https://doi.org/10.1177/0022487193044004004

Coşkun, E., Gelen, İ., \& Öztürk, E. P. (2009). Proficiency Perceptions of Pre-Service Turkish Language Teachers About Educational Planning, Application and Evaluation. Mustafa Kemal Üniversitesi Sosyal Bilimler Enstitüsü Dergisi, 
6(12), 140-163.

Coşkun, E., Özer, B., \& Tiryaki, E. N. (2010). An Evaluation of Competency Perceptions of Prospective Turkish Teachers. Dokuz Eylül Üniversitesi Buca Eğitim Fakültesi Dergisi, 27, 123-135.

Çalışkan, M., Işık, A. N., \& Saygın, I. (2013). Prospective Teachers' Perception of Ideal Teacher. Elementary Education Online, 12(2), 575-584.

Çulha, B. (2010). Characteristics of a good history teacher: Teaching typology. M. Safran (Ed.), Tarih nasıl ögretilir? [How is history taught?] (pp. 367-372). İstanbul: Yeni İnsan Yayınevi.

Dönmez, C., \& Uslu, S. (2014). The Examination of Social Studies Teacher Candidates' Self-Efficacy Beliefs Related to Special Field Competencies in Terms of Various Variables. Abant İzzet Baysal Üniversitesi Eğitim Fakültesi Dergisi, 14(1), 460-482.

Ereş, F. (2010). Opinions of Primary Education Inspectors Intended for Personal and Professional Values and Professional Development Competencies within General Workframe Proficiencies of Primary School Teachers. Gazi University Journal of Gazi Educational Faculty, 30(2), 357-374.

Erkan, S. (2011). The current situation of history teaching in universities. M. Öz (Ed.), Cumhuriyet döneminde Türkiye'de tarihçilik ve tarih yazıcllı̆̆ [Historiography in Turkey during the republican era] (pp. 237-289). Ankara: Türk Tarih Kurumu Basımevi.

Gelbal, S., \& Kelecioğlu, H. (2007). Teachers' Proficiency Perceptions of About the Measurement and Evaluation Techniques and The Problems They Confront. H. U. Journal of Education, 33, 135-145.

Gelen, İ., \& Özer, B. (2008). Having General Adequacy of Teaching Profession Evaluation of the Views of Teacher Candidates and Teachers about Their Level. Mustafa Kemal Üniversitesi Sosyal Bilimler Enstitüsü Dergisi, 5(9), $39-55$.

Gökçe, E. (2003). Primary school teacher training practices in developed countries, International conference on World teacher education. (27 Ağustos-2 Eylül 1995). Ankara: MEB Öğretmen Yetiştirme ve Eğitimi Genel Müdürlüğü.

Grant, S. G. (2003). Historylessons: Teaching, learning, andtesting in U.S. high school classrooms. Mahwah:Lawrence ErlbaumAssociates.

Gündüz, T. (2011). On the curriculums of history departments. M. Öz (Ed.), Historiography in Turkey during the republican era (pp. 227-236). Ankara: Türk Tarih Kurumu Basımevi.

Hacığlu, F., \& Alkan, C. (1997). Teaching practices. Ankara: Alkım Kitabevi

Husband, C. (2011). What do historyteachers (need to) know?, I. Davies (Ed.), Debates in history teaching (pp. 84-95). London and New York: Routledge.

Kahramanoğlu, R., \& Ay, Y. (2013). Examination of the Primary Teacher Candidates' Special Field Competence Perceptions as to Different Variables. International Journal of Turkish Literature Culture Education, 2(2), 285-301.

Kahyaoğlu, M., \& Yangın, S. (2007). İlköğretim öğretmen adaylarının mesleki öz yeterliklerine ilişkin görüşleri. Kastamonu Ĕ̈itim Dergisi, 15(1), 73-84.

Karabağ, Ş. G. (2010). Elements shaping the professional skills of history teachers. M. Safran (Ed.), How is history taught? (pp. 373-376). İstanbul: Yeni İnsan Yayınevi.

Karacaoğlu, Ö. C. (2008). The Perceptions of Teachers' Sufficiency. Yüzüncü Yll Üniversitesi Eğitim Fakültesi Dergisi, 5(1), 70-97.

Karagözoğlu, G. (2003). A look on teacher training policy in education system. Reflections on Education: The 7th teacher training symposium in contemporary education systems. Sivas: Cumhuriyet Üniversitesi Kültür Merkezi.

Kıncal, R. (2004). Introduction to teaching profession. İstanbul: Nobel Akademi Yayınc1lık.

Kitson A., Husbands, C., \& Steward, S. (2011). Teaching and learninghistory 11-18: understanding the past. Berkshire: McGraw Hill Open UniversityPress.

Kök, M., Çiftçi, M., \& Ayık, A. (2011). An Examination on Teachers Competencies in Their Branches (Sample of Early Childhood Teachers). Atatürk Üniversitesi Sosyal Bilimler Enstitüsü Dergisi, 15(1), 169-183.

Köksal, N. (2008). Assessment of Generic Competences of Teaching Profession by Teacher, School Director and Consultants from the Ministry of National Education. Pamukkale Üniversitesi Eğitim Fakültesi Dergisi, 23(1), $36-46$.

MEB (2006). The project of basic education: Component of teacher education. Ankara: MEB Öğretmen Yetiştirme ve 
Eğitimi Genel Müdürlüğü.

MEB (2011). Ministry of national education general directory of teacher training and education project of secondary education: special field competencies of history teachers. Ankara: Milli Eğitim Bakanlığı.

MEB. (2008a). Teacher competencies: general and special field competencies of teaching profession. Ankara: Devlet Kitapları Müdürlüğü.

MEB. (2008b). General competencies of teaching profession. Ankara: Devlet Kitapları Müdürlüğü.

Öner, D. (2010). Is the Teacher's Knowledge a Special Knowledge? A theoretical overview of the necessary knowledge to teach. Boğaziçi Üniversitesi Ĕgitim Dergisi, 27(2), 23-32.

Özbek, R., Kahyaoğlu, M., \& Özgen, N. (2007). Evaluation of Candidate Teachers' Opinions on Teaching Profession. Sosyal Bilimler Dergisi, 9(2), 221-232.

Özdemir, S. M. (2008). An Investigation of Prospective Primary Teachers' Self-Efficacy Beliefs Regarding Teaching Process in Terms of Certain Variables. Educational Administration: Theory and Practice. Spring, 54, 277-306.

Özdemir, S., Yalın, H. İ., \& Sezgin, H. (2004). Introduction to teaching profession. Ankara: Nobel Yayınc1lı.

Öztürk, İ. H. (2016) Teaching of European history. M. Safran (Ed.), How is history taught? (pp. 371-378). İstanbul: Yeni İnsan Yayınevi.

Öztürk, M. K. (2009). The Opinions and Self-Evaluations of Social Studies Teachers Concerning the Competency Area of School, Parents and Society Relations. Bilig, 49, 113-126.

Seferoğlu, S. S. (2004). Teacher Competencies and Professional Development. Bilim ve Aklın Aydınlı̆ğnda Eğitim Dergisi, 58, 40-45.

Shulman, L. S. (1986). Those who understand: knowledge growth in teaching. Educational Researcher, 15(2), 4-14. https://doi.org/10.3102/0013189X015002004

Shulman, L. S. (1987). Knowledge and teaching: foundations of new reform. Harvard Educational Review, 57(1), 1-22. https://doi.org/10.17763/haer.57.1.j463w79r56455411

Smith, N. (2010). The history teacher's handbook. New York: Continuum International Publishing Group.

Şahin, A. E. (2004). Determination of teacher competencies. Bilim ve Aklın Aydınlığında Eğitim Dergisi, 5(58).

Şeker, H., Deniz, S., \& Görgen, İ. (2005). Prospective Teachers' Assessment of Teacher Competencies. Educational Administaration: Theory and Practice, 42, 237-253.

Taşdemir, M. (2007). Primary School Teachers' Perception Of School, Colleague Proficiency And Self Proficiency. Milli Ë̆itim, 174, 171-192.

Tunca, N., \& Şahin, S. A. (2014). The Relationship Between Pre-Service Teachers' Metacognitive Learning Strategies and Academic Self-Efficacy. Anadolu Journal of Educational Sciences International, 4(1), 47-56.

Yeşil, R. (2009). Training Qualifications of Social Studies Candidate Teachers in Class (The Sample of Kirsehir). Türk Ĕ̈itim Bilimleri Dergisi, 7(1), 23-48.

Yeşilyurt, E. (2011). Teacher Candidates' Qualification Perceptions About Teaching Profession's General Qualifications. Türk Ë̆itim Bilimleri Dergisi, 9(1), 71-100.

Yıldırım, T., \& Yazıc1, F. (2017).Scale of perceived competence in history as a subject matter: A scale development study. Turkish Studies 12(17), 589-604. https://doi.org/10.7827/TurkishStudies.11836

Yüksel, H. (2011). Historiography in rural universities. M. Öz (Ed.), Historiography in Turkey during the republican era (pp. 215-226). Ankara: Türk Tarih Kurumu Basımevi.

\section{Copyrights}

Copyright for this article is retained by the author(s), with first publication rights granted to the journal.

This is an open-access article distributed under the terms and conditions of the Creative Commons Attribution license which permits unrestricted use, distribution, and reproduction in any medium, provided the original work is properly cited. 